\title{
Democracy Of Islamic Education: Building A Monochotomic Epistemology In Islamic Education
}

\author{
Siti Masyitoh ${ }^{1}$, Nur Sodik ${ }^{2}$, Iik Arifin Mansurnoor ${ }^{3}$, \\ Mohamad Azmi Musyaffi ${ }^{4}$, Zulkifli $^{5}$, Abudinata $^{6}$ \\ \{siti_masyitoh19@mhs.uinjkt.ac.id'1,nur.sodik@unindra.ac.id², iik.arifin@uinjkt.ac.id², \\ mohamad.azmi20@mhs.uinjkt.ac.id ${ }^{4}$, zulkifli@uinjkt.ac.id ${ }^{5}$, abudinata@uinjkt.ac.id $\left.{ }^{6}\right\}$
}

Postgraduate School of Syarif Hidayatullah State Islamic University of Jakarta, Indonesia ${ }^{123456}$

\begin{abstract}
Democracy in Islamic education includes values such as justice, deliberation, equality, freedom, plurality and tolerance as the basis for all Islamic education activities so that there is freedom of interaction between educators and students in the learning process in class. The current crisis in Islamic education still emphasizes the doctrinairenormative aspects which tend to be exclusively apologetic but transcendental. The ideological paradigm and the scientific paradigm mix causing uncertainty. The dualismdichotomous phenomenon between religious (semitic) and general (helenistic) science develops, while the creative, dynamic tradition of scientific thought as demanded by Islamic teachings is difficult to develop. This paper uses a research library research type. For data collection, the researcher used descriptive analysis method where the data which became the object of study after being analyzed then described it. This paper describes a picture of the ideal Islamic education which is reconstructed and reformed through monocotomic epistemology as a new direction of Islamic education that is more democratic and based on the spirit of Islamic teachings that integrates the realm of religious and general knowledge so that through the educational process it brings understanding and awareness of God's power.
\end{abstract}

Keywords: Educational Democracy, Epistemology, Monochotomics.

\section{Introduction}

In the course of its history, Islamic education has been able to shape civilizations that have colored the Arabian Peninsula, West Asia, and Eastern Europe. However, along with the decline of Islam, Islamic education also experienced its decline. Even within the paradigm, there is a shift from an active-progressive to a passive-defensive paradigm. As a result, Islamic education undergoes a process of 'self-isolation' and is marginalized from the environment in which it is located. The trend of Modernism which is marked by the victory of rationalistic positivistic logic has been able to color in all fields of scientific studies, both natural and social sciences. But in fact, the positivistic-rationalistic logic with the slogan 'science is value-free or neutral' means that science does not pay attention to human values and religious values. This situation has been considered endangering human life because it attacks fundamental structures. Subsequently, a new idea emerged which called itself postmodernism in the 1990s in which there were global economic and information phenomena. It has even changed the pattern of relations to replace the hierarchy as the main capital to solve all the problems of life. [1] 
One side of Islamic education is in an atmosphere of modernization and globalization, it is required to be able to play its role dynamically and proactively. To be able to contribute and meaningful positive changes for the improvement and progress of Muslim civilization, both on the theoretical and practical intellectual plains. Islamic education must be able to play an active role as a generator that has the power to liberate it from the pressures and pressures of socio-cultural backwardness, ignorance, economy, and poverty amidst rapid social mobility. On the other hand, Islamic education faces problems that require an effective and efficient strategy in solving various problems caused by modernism such as the moral decadence of mankind and also faced with the problem of sunnatullah, namely pluralism [1] whether culture, politics, religion, thought and so on, or even the development of value-free science and technology.

In the course of Islamic education, there are two patterns of thought about traditionalist (eastern) education which emphasizes more on the doctrinal-normative aspects that tend to be exclusive-apologetic. And the modernist style (Western-style) which in its development begins to lose its basic (transcendental) souls. Both of these educational models resulted in the ambivalence of Islamic education orientation, [2] which one of the negative impacts is dualism-dichotomous. Besides that, the current paradigm of Islamic education is still centralized, meaning that education is centered/dominated by certain groups, while the orientation of educational development is more partial.

So that Islamic education does not lose direction, the solution to these problems, the author tries to conduct a study by discussing aspects that will become the main foothold of Islamic education in integrating these two domains by formulating a new paradigm, namely combining two systems of thought, positivistic-rationalistic with religious- normative. The form of the solution is to build a new direction of Islamic education that is more democratic and normative-oriented with the spirit of monochromic epistemology, namely "integrating" the realm of science and the results of science in the form of technology with the spirit of faith (tauhid). Especially in the contemporary context, science and technology have been segmented in a polarized area between East and West or with vulgar language between Protestants and Islam. This condition will encourage policies and development strategies by optimizing the importance of information and communication technology (ICT) for Islamic education and provide room for teachers to improve the quality of Islamic education.

\section{Discussion}

\subsection{The Concept of Islamic Education Democracy}

\subsubsection{The Concept of Educational Democracy}

Democracy is a political term, but its criticism does not only exist in political life. [3] Democracy is another expression of respect for human rights, an attitude of human life that reflects the belonging and upholding of civilization and culture. [4] Democratic education according to Vebrianto is education that provides equal opportunities for every student to reach the highest educational level according to their abilities. [5] Meanwhile, Sugarda Purbakawatja defines educational democracy as teaching education in which all members of society (learning citizens) receive fair education and teaching. 
In general, educational democracy can be interpreted as an order in which democratic values, such as justice, deliberation, equality, freedom, plurality, and tolerance, are used as a foundation or principle in all educational programs and practices. Meanwhile, Sugarda Purbakawatja defines educational democracy as teaching education in which all members of society (learning citizens) receive fair education and teaching.

In general, educational democracy can be interpreted as an order in which democratic values, such as justice, deliberation, equality, freedom, plurality, and tolerance, are used as a foundation or principle in all educational programs and practices. [6] Educational democracy means the freedom given to education actors to increase progress in the world of education [7] The more democratic the implementation of education in a country will have implications for increasing the level of public awareness of their rights and obligations in using their minds, energy, and voice. The very strong impact of the application of educational democracy is the development of diversity in people's mindsets, creativity, and high innovation power.

Educational democracy can be seen from two points of view. First, horizontal democracy, namely that every student must have the same opportunity to enjoy education (school). Second, vertical democracy, that every child gets the same opportunity to reach the highest level of school education, according to their abilities. [8]

The development of educational democracy that is oriented towards democratic ideals and values will always pay attention to the following principles [9] 1) Upholding human dignity by noble values; 2) Respecting and protecting human rights with dignity and virtue; 3) Striving for the fulfillment of the right of every citizen to obtain national education and teaching by utilizing their abilities, to develop their creations towards the development and advancement of science and technology without harming other parties.

Educational democracy is a democracy that provides equal educational opportunities to all people, regardless of race (ethnicity), creed, color, and social status. This definition implies that every individual has the same right to obtain education and teaching. [10] In Taman Siswa, the Tutwuri Handayani attitude was adopted, a democratic attitude that acknowledged her right to grow and develop according to her nature. [11] Democracy in education is also interpreted as recognition of individual students, by the dignity of the students themselves because democracy is natural and human [12] This implies that the parties involved in the education process must recognize and respect the diversity of abilities and individual characteristics of students. And the element of coercion is not justified [12] in the educational process

According to Paulo Pere, to create educational democracy there needs to be freedom of interaction between educators and students in the learning process in class. In this context, the learning atmosphere must be encouraged to lead to a healthy and responsible dialogue atmosphere between educators and students, between students and students, and takes place in an egalitarian and equal atmosphere.

In educational democracy, apart from freedom of interaction, it also requires inherently dialogical communication, namely: 1) Communication takes place in all directions and is not one-way between educators and educators (top-down) 2) Communication takes place in a balanced manner, namely between educators and students and between students with other students. In educational democracy there will be a three-way dialogue (educators, students, between students) so learning resources are not only from educators but also students, and the teaching model is not only top-down but also must be balanced with bottom-up. but also students, and the teaching model is not only top-down but also must be balanced with bottomup. [13] 
According to Dede Rosyada, the term democracy appears and is used in political studies, which means that power is in the hands of the people. With the nature of the democratic (political) mechanism, it does have differences and is not entirely compatible with the democratic mechanism in education, but substantially democracy brings enthusiasm to education, both in planning, management, and evaluation [14] In its application, educational democracy will place students as the center of attention and be placed as human beings. Education must provide services that are conducive to the optimal growth and development of children. [15]

Educational Democracy is a view of life that expresses equal rights and obligations and equal treatment in the ongoing process of education between education and students, as well as with education managers. Thus educational democracy is not just a procedure, but also the values of recognition in human honor and dignity [7] although currently the government is still trapped in procedural democracy and pays less attention to education. [16]

\subsubsection{The Concept of Islamic Education Democracy}

Democracy in Islam has the first several terms: Shura is a principle about the way of deliberative decision making. Second, Al-'is namely justice. Third, Al-Musawah is parity, meaning that no party feels superior to the other so that they can impose their will. Fourth, AlAmanah is an attitude of fulfilling the trust that one gives to others. Fifth, Al-mas'uliyyah is a responsibility, sixth, Al-hurriyyah is freedom, meaning that everyone is given the right and freedom to express their opinions. The term democracy comes from ancient Greece but in the Islamic world, it has its traditions and text interpretations. [17]

The reality is that there are differences of opinion among Muslims regarding the relationship between Islam and democracy. Some argue that democracy has no historical value and arguments support so that its existence must be rejected. [18] This rejection is because democracy is defined as a power in the hands of the people and this contradicts the Islamic doctrine that only God has power. Besides, democracy is an idea from the west, according to John L. Esposito, even this rejection is based on anything as a whole against European colonialism. [18] The scholars who refuse to claim that Islam is a complete religion that governs all aspects of life. [19]Thus, there are two problems regarding the relationship between religion and democracy: First, the philosophical problem, namely that if the claims of religion against its adherents are so total, democracy will shift the autonomy of human freedom, which means it also shifts the principles of democracy. Second, the historical sociological problem, the role of religion is often used by the authorities to support their political interests. [19]

Others argue that democracy is similar to Islam and has significant similarities.[20] The ideas put forward by both Abdurrahman Wahid [21] and Nurcholis Madjid [19] state that religion supports the democratic process. Islam is a religion of democracy for the following reasons, first, Islam is a religion of law, so people must be treated equally. Second, Islam has a principle of deliberation (shura), to unite various desires and desires. Third, Islam always has a view of improving life. Fourth, Islamic democracy also puts forward the principles of justice. According to Nurcholis Madjid, there is a meeting point between religion and democracy, especially when it is linked to both goals, namely the ideal for the good of all. So it is not surprising that the acceptance of Muslims to democracy is very natural,

To be able to find a relationship between Islam and democracy, one must first explore the values of democracy in Islam itself. [22] The values of Islamic teachings that can be developed in the concept of democracy are a) The principles of freedom, namely freedom of 
thought, freedom of belief, and freedom of opinion. Sharia upholds these principles and commands every Muslim to make them come true [23] b) The principle of justice is the basic principle of Islamic ideology, which should not be partial, one cannot differentiate between a person's social status, wealth, class, race, political influence, or religious beliefs. [23] (QS. AlMaidah: 8) c) The principle of equality which in essence, humans are "one family". This "uniform" process of creation is proof that basically all humans are the same. Therefore, humans have the same position (QS.Al-Hujurat: 13) d) The principle of deliberation, which is a joint effort with a humble attitude to solve problems (find a way out) to make joint decisions in solving or solving problems related to affairs worldliness.

The use of the term "democracy" which is an upturned word from a foreign language into the discourse of Islamic education requires carefulness and caution because the word democracy has become a difficult concept to define. This difficulty is even felt in a political context. [24] Islamic education democracy includes: First: Freedom for educators and students. Freedom here includes 1) Freedom to work, according to al-Abrasyi, to educate students must accustom their students to hold fast and be given freedom of thought so that they can freely determine their future based on their abilities. [25] 2) Freedom to develop potential (Fitrah) Islamic teachings greatly provide freedom to students in developing the values of fitrah that exist in them both fitrah al-gharizah and fitrah al-munazalah [26] to harmonize with the times. 3) Freedom of opinion, where educators guide and direct students to express their hearts in a manner that is natural, moral and praiseworthy and pleased by Allah SWT by the stages of development of their souls, not freedom of opinion which results in their soul being shackled as it is anxiety, anxiety, and disappointment during the teaching and learning process. Second: Equal learning opportunities for students. According to Abuddin Nata, students when in a room have equal opportunities to get an education with the aim of acquiring knowledge together. [27] Third: Respect for individual dignity, an educator must be respectful of opinions and treat students with respect that is by their dignity because in this way democratic situations and conditions will be created in the teaching and learning process. [28]

\subsubsection{The Dynamics of Islamic Education Democracy Application}

The application of Islamic education democracy has consequences for the formation of decentralization of authority, where on the one hand the management of education will be largely determined by the direct executor, both managers, educational staff, and the community in creating content or material, learning systems, including developing the quality of students. On the other hand, educational democracy will also have an impact on aspects of the curriculum, administrative efficiency, income, and cost of education, as well as equity in the acquisition of public education.

The fundamental problem of Islamic education is the unclear paradigm of Islamic education. The ideological paradigm and the scientific paradigm are mixed in such a complex way that what develops later is the scientific ideological paradigm or the pseudo-scientific paradigm. . [29] As a result, the tradition of creative, dynamic, and open scientific thought in the Islamic tradition, as well as the nature of revelation, is really difficult to develop [30]

Today, it is felt that the existence of Islamic education from the perspective of the ritual dimension is still far from providing spiritual, ethical, and moral divine enrichment. [31] so that students can cognitively understand Islamic teachings and are skilled in implementing them, but do not appreciate the depth of its meaning, one of the causes is the existence of two scientific entities that are positioned diametrically between one another, namely between 
religious science (Semitic) and general science (Hellenistic). [32] The paradigmatic dichotomy of science has led Islamic civilization to progressive stagnation.

Historically, the causes for the decline of Islamic education include the 'scientific dichotomy'. According to al-Faruqi, there are at least two main causes for the dichotomy of education in the Islamic world, namely: 1) Western imperialism and colonialism over the Islamic world, this condition causes the powerlessness of Muslims to reject the notion that shari'ah is perfect and there is no need for innovation or not. there is another opportunity for doing ijtihad while western sciences are developing to replace the position of religious sciences. The danger is that this situation has an impact on the Islamic school curriculum so that in the educational process there is a dichotomous between religious science and secular general science[33] The separation between thought and action among Muslims is the challenge that should be thrown by western scholars responded positively and wisely by Islamic thinkers so that they can assimilate new knowledge and can give it direction[34] According to Al Faruqi, every aspect should not be dichotomized and must maintain relevance to the three axes of tawhid, namely First, the unity of knowledge; second, the unity of life; and third, historical unity.

According to Ikhrom the dichotomy of general sciences and religious sciences has the following consequences: 1) The emergence of ambivalence in the Islamic education system; 2) The emergence of a gap between the Islamic education system and Islamic teachings. 3) The disintegration of the Islamic education system, in which each western (modern/general) and religious (Islam) system remains adamant about defending itself or egoism. [35] 4) The emergence of inferiority in the management of Islamic education institutions. This is because western education does not respect cultural and moral values.

The solution to these problems is by fixing the internal fundamental problems of Islamic education, including First: integrating religious and general sciences. Azyumardi emphasized that Islamic education institutions must have a vision of Islam, modernity, current, future, and humanity to be compatible with the times. [25] Second, reorientation of thinking about the goals and functions of Islamic educational institutions. According to KH. Abdul Wahid Hasyim the current educational process dynamically by actualizing and contextualizing theology is needed to reconstruct the philosophical basis of Islamic education which can direct the educational process to better success. [36] himself. [37] Ibn Khaldun in his muqaddimah stated that the implementation of Islamic education must begin with a balance so that these students can get happiness both in the world and in the hereafter. [38] Islamic Religious Education places talab al-ilm under the framework of religious work. There is a balance between the religious disciplines and intellectuality in the curriculum; carry out a down-toearth education strategy. [11] Empirically the application of democratic attitudes in the Muslim world has a much more favorable tendency [39] including education.

In Southeast Asia, Islamic education has an important and well-developed role. One of them is keeping the Muslim community in Southeast Asia rooted in moderate but tolerant values. As for the education system in general, there is no dichotomic between general and religious education, such as in Indonesia the practice of education is multi-religious, in Malaysia, even though Islam is the country's official religion, it practices general teaching, in the Philippines, there is no separation of religion and state, even the government permits for cooperation religious groups to teach moral values in public schools during school hours. [40] The education model in Pakistan aims to create citizens loyal to the theocratic state governed by the Quran. [41] Pakistan carries out 'enlightened moderation', which is transforming liberal democracy into a national social environment, so that the education critique must be practiced leading to its final goal of preparing students who are democratic, tolerant, caring, and peace- 
loving and have the knowledge, values, attitudes, and skills of civic participation. necessary to live in harmony with each other. [41]

Islamic education democracy can refer to the following Islamic teachings: 1) Islam requires people to seek knowledge 2) There is an obligation to ask experts in science. In the context of its implementation, according to Hasbullah, [8] the democratic process of Islamic education takes place between educators and students in social interactions, both individually and collectively, and can be in the form of face to face to the use of print or electronic media. Therefore, in its implementation, it refers to the guidelines including (a) Mutual respect is a form of feeling that humans are creatures that are glorified by Allah SWT. (b) The delivery of teaching must be in language and practice based on kindness and wisdom. (c) Fair treatment of students. (d) The development of affection between educators and students. (e) Embedding it in the souls of educators and students will the need for taufiq and guidance from Allah SWT.

\subsection{New paradigm in Islamic education democracy}

Paradigm contains meaning 1). The case was used as a sample or sample, 2). Framework for basic concepts and postulations that are used as references in the research process, 3) Model in scientific theory, 4). The link lists all the formations of a word showing the conjugation and declination of the word. [42] According to Mahmud, Paradigm is 1) a way of looking at something, 2). Models, patterns, ideal. From these models various phenomena are viewed and explained, 3). Total theoretical and methodological premises that determine and describe a concrete scientific study. [43] So the paradigm is oriented towards basic meaning, a way of looking at something, and the ability to make descriptions that drive change

Education that has a strategic and functional role requires a new paradigm that must emphasize changing ways of thinking in the management and implementation of education [44] In Islamic education, the new paradigm referred to here is a thought that must continually be developed through education to reclaim science and technology leadership, as it was in the past. [44] For Indonesianness, a fundamental and comprehensive reform of national education must start from finding new explanations for the paradigm of the role of education in development. [45]

Meanwhile, the new paradigm in Islamic education starts from the concept of man according to Islam, the Islamic view of science and technology, and after that, the concept or system of Islamic education is formulated as a whole. Islamic education which is developed based on the new paradigm is oriented towards the following: 1) theocentric and anthropocentric philosophy at the same time. 2) Building science and integrated life progress between spiritual, moral, and material values for human life. 3) Building human competition and preparing for life a better democratic, competitive, innovative human-based on Islamic values. 4) Compiled based on the environmental conditions of the community, both present conditions, and conditions in the future. 5) Empowering the potential of the people by the needs of life and developed based on the characteristics of a democratic civil society, having the ability to social participation, obeying and respecting the rule of law, respecting human rights, respecting differences [pluralism], having competitive abilities and innovative abilities. 6) Management and curriculum preparation must be adapted to the demands of democratic and decentralized education. Islamic education must be able to develop the ability to participate in the world of work, develop innovative attitudes and abilities, and improve human quality. 7) It emphasizes and is oriented towards the learning process, organized in a structure that is more flexible, respects and treats students as individuals who have the potential to develop, and 
strived for as a continuous process and constantly interacting with the environment. 8) It is directed at two dimensions, namely "First, the dialectical dimension [horizontal], namely developing an understanding of human life in relation to its social environment and being able to overcome the challenges of the surrounding world through the development of science and technology, and Second, the dimension of vertical submission, namely education other than a means of strengthening, maintaining natural resources and the environment also understanding its relationship with the Creator, namely Allah SWT. " children with an integrative perspective, as a vehicle to build a unified character, produce democratic humans, produce humans who care about the environment ", and a view must be built that" schools are not the only educational instrument "because in the current information age, knowledge can be obtained from various electronic media and mass media, such as: the internet with the role of the web, homepage, cd-rom, discussions on the internet, and television, radio, newspapers, magazines which are tools that will greatly accelerate the process of distributed knowledge.

Paradigm change should also be implemented at the implementation level, especially in the implementation of the learning. Paulo Feire, followed by Yatim Riyanto, gave educational directions that play a liberating role where the situation of teachers and students alike has differences. berperan membebaskan dimana situasi guru dan peserta didik sama-sama memiliki perbedaan. [46] In modern learning, learning takes place with dialogue, the meaning is 1) freedom for students to seek and convey the knowledge they have, 2). There is no distance between students and other students, between students and teachers, 3) Build positive competency values among students, 4) Instill mutual respect and respect for the findings and opinions of each student, 5). teachers can observe and understand the differences that occur among students, differences in knowledge, attitudes, and personalities, 6). Build trust, sympathy, and empathy for both students and teachers. Thus the synergy of democracy in Islamic Education is a source of values to build the character of the nation. ${ }^{1}$

\subsection{A New Direction In Democracy In Islamic Education: Building A Monochotomic Epistemology}

Epistemology in Arabic terminology is called nadhariyyah alma'rifah or scientific theory and is a branch of philosophy that parses and analyzes the nature and scope of knowledge, basics, sources, goals, and classification of knowledge as well as developing postulations and accountability for questions. regarding that knowledge. Furthermore, from epistemology, emerges the structure of science down to its sub-branches ${ }^{2}$

Epistemology is used to construct theories in a scientific discipline to be accounted for empirically and rationally. According to Ahmad Tafsir, the integration of rational (ism) and empiric (ism) in one epistemological package gives birth to the scientific method. It is through these two conditions that the authoritative-credibility of science can be proven. [47]

Secular epistemology is only based on reason (rational) and empirical power alone, whereas in Islamic education epistemology knowledge is not only based on these two factors but also comes from revelations from the Al-Quran and Sunnah. That revelation is precisely the highest quality of basic science. Revelation that guides, directs, controls, and inspires epistemology. Islamic education comes directly from Allah and the Prophet Muhammad.

\footnotetext{
${ }^{1}$ M. Fahmi, "Pendidikan Islam ,Demokrasi dan Kewarganegaraan,.., JOIES J. Islam. Educ. Stud., vol. Volum.1,67

${ }^{2}$ M. Arif, Pendidikan Islam Transformatif. Yogyakarta: LKIS, 2008, 61
} 
The reform of Islamic epistemology in the world of education, especially Islamic education, is very important to be carried out to produce quality and educative education, especially in the current crisis concerning science and technology. The epistemological approach opens the awareness and understanding of students to obtain the necessary knowledge in a certain way or method and provides an integral and comprehensive understanding and skills. Epistemology is a process-based approach. The epistemological position in Islamic education gives birth to logical consequences, namely: a) Eliminating the dichotomous paradigm between religious and general sciences, science is not value-free, but free to assess, b) Changing the pattern of indoctrinated Islamic education into a participatory and demanding pattern student to be equally active in the teaching and learning process. c) Changing the ideological paradigm into a scientific paradigm that is based on the revelation of Allah SWT. The ideological paradigm does not provide room for reasoning or free thinking, while the scientific paradigm based on the basis of revelation is argumentatively responsible and revelation gives the human mind the flexibility to study, research, observe, discover, science (ayat kauniyah) with the guidance of Allah's revelation. SWT (Qs Al-Ghosyiyah verses 17-20). Proof of scientific paradigm based on the truth of revelation can be known by conducting research, observation, discovery and development so that the results arrive at the conclusion that knowledge comes from Allah and is used by humans to carry out their duties as khalifatullah and as Abdullah to achieve happiness in the world and in the hereafter. . d) Reconstructing a secular and spiritual value-free curriculum into a curriculum based on tauhid. The orientation of Islamic education is emphasized on integrated growth between faith, science, charity, and morals and this means changing the theoretical or conceptual approach to a contextual or applicable approach.

Normatively, Islam has provided a strong foundation for the implementation of education. First, Islam emphasizes that education is a religious obligation where the process of learning and transmission of knowledge is very meaningful for human life, this process contains the meaning orders to make observations, explore knowledge, experimentation, study, study, analyze, research, research, write science comprehensively ( QS. Al-Alaq: 1-5) Second, the whole series of implementation of education is worship to Allah. As a form of worship, education is an individual as well as a collective obligation (QS. Al-Hajj: 54). Third, Islam gives a high degree to educated people, scholars, and scientists. (QS. Al-Mujadalah: 11) Fourth, Islam provides the basis that education is a lifelong activity (long-life education) [48] or even as the Prophet's Hadith about studying from the mother's cradle to the burrow tomb. Fifth, the construction of education according to Islam is dialogical, innovative, and open in accepting knowledge from both East and West.

The success of building an Islamic education that can become a shield for the modern era indicates the following criteria: First; Educators must have high moral integrity by prioritizing ethics as their personalities, Second; the philosophical foundation of Islamic education which has been dichotomized into a monochromic philosophical value with the normative basis of God's verbal revelation, namely the Al-Quran and Hadiths to provide morality values in the form of akhlaq karimah to mediate models of radical Islamic understanding. [49] Holisticintegralist Islamic education, especially in the field of religion, is the foundation of spiritual intelligence and emotional intelligence, namely: 1). Unity in the aspect of divinity and His message (revelation); 2). Prophetic unity; 3). There is no compulsion in religion, and 4). Recognition of the existence of other religions. Everything like this is called normative because it is God's decree.

The development and application of Islamic education require prophetic ethics, namely ethics developed based on divine values (qauliyah) for the development and application of 
knowledge. The values of the Koran that can be developed for prophetic ethics for the development and application of Islamic education [50] are 1) Value of Worship, namely for stakeholders of Islamic education, its development and application is worship (Surah Adzdzariyat: 56 and Ali Imrān: 190-191) .1) Ihsan's value, namely doing good to all parties and prohibited from doing damage in any form (QS. Al-Qashas: 77).3) Future value, namely the science of Islamic education should be aimed at anticipating a better future, because educating means preparing a generation that will live and face future challenges that are far different from the previous period (QS. Al-Hashr: 18) 4) The value of mercy, namely the science of Islamic education should be aimed at the interests and benefits of all mankind and the universe (QS. Al-Anbiyā: 107) 5) The value of trust, which is the mandate of Allah for the holder so that its development and application is carried out with the intention, method, and goals as desired by Him (QS. Al-Ahzāb: 72) 6) The value of da'wah, namely the development and application of Islamic education is a form of dialogue of da'wah or conveying Islamic truth (QS. Fushshilāt: 33) 7) The value of tabshir, which is always giving good hopes for mankind about their future, including maintaining balance or preservation of nature (QS. AlBaqarah: 119).

Alex R. Rodger stated that Islamic religious education is an integral part of education in general and serves to foster the understanding needed for people of different faiths, as well as to strengthen the orthodoxy of faith for them[51] Integral education of religious knowledge and general science influences the internalization of religion or the practice of the life of the perpetrator. This is very important to formulate and establish as an integral part of creating Islamic education as a center of learning and research as well as an agent of change in society [52]

Thus Islamic education becomes an educational system that can offer a concept with a very high "bargaining power", namely changing the ignorant community into the best people. The offer is carried out in 3 (three) stages of activity, namely: recitation (reciting the verse of Allah), tazkiyah (purifying the soul) and ta'limul Kitab wa Sunnah (teaching al-Kitab and alhikmah) so that with these 3 stages Islamic religious education becomes an integral part of Muslims at a practical level. [53] however, for some Muslim countries such as Arab (Israel) the practice of democracy in Islamic education experiences significant obstacles, this is due to cultural factors of the people. [54]

\section{Conclusion}

Islam has advised its followers to treat others as they treat themselves. Islam also calls for the principle of equality and equal opportunities in learning without any differences. Educational democracy, both horizontally and vertically, requires the active participation of all elements in determining education policy. Through the classic problematic bottom-up mechanism in contemporary education to this day is an internalization effort between two scientific entities that are positioned diametrically between one another, namely between the science of religion (Semitic) and general science (Hellenistic). Meanwhile, the education system which can produce educational outputs and outcomes by ideals must be based on the underlying philosophy, especially the epistemology.

The reform and reconstruction of monochromic epistemology in Islamic education as a new direction for the paradigm of Islamic education is very important because there are efforts to integrate between the realms of religious knowledge (Semitic) and general science 
(Hellenistic) as well as the results of both sciences in the form of technology with the spirit of faith (tauhid). ). Even this spirit seeks to integrate and combine the two systems of thought, positivistic-rationalistic and religious-normative. Thus the epistemological change animates the entire operational management function of Islamic education into a professional management system with the spirit of Islamic teachings and can produce humans who have extensive knowledge and master technology by sticking to the religion of Allah 


\section{References}

[1] Z. Zamroni, "Arah Baru Pendidikan Islam: Membangun Epistemologi Pendidikan Islam Monokhotomik," Din. Ilmu, vol. 10, no. 2, 2010.

[2] A. M. Saifuddin, Desekularisasi Pemikiran. Bandung: MIzan, 1998.

[3] M. (ed.)William, Dictionary of English Language. New York: Hoghton Mifflin Company, 1979.

[4] S. dan A. B. Arifin, Paradigma Pendidikan Berbasis Pluralisme dan Demokrasi, Rekonstruksi dan Aktualisasi Tradisi Ikhtilaf dalam Islam. Malangm: UMM Press.

[5] S. Vebrianto, Kapita Selekta Pendidikan II. Yogyakarta: Paramita, 1998.

[6] S. Idris, "Demokrasi dan Filsafat Pendidikan (Akar Filosofis dan Implikasinya dalam Pengembangan Filsafat Pendidikan).” Ar-Raniry Press, 2014.

[7] M. R. Daulay, ““”Demokrasi dalam Perspektif Filsafat Pendididkan Islam “,” Fitrah J. Kaji. Ilmu-ilmu Islam, vol. 3 no 1, 2017.

[8] Hasbullah, Dasar-dasar Ilmu Pendidikan. Jakarta: Raja Grafindo Persada, 2001.

[9] I. Djumberansyah, Filsafat Pendidikan. Surabaya: Karya Abditama, 1994.

[10] S. Poerbakawatja, Ensiklopedi Pendidikan. Jakarta: Gunung Agung, 1982.

[11] S. Sanuri, "Demokrasi dan Humanisasi Pendidikan Relevansinya Dengan Pendidikan Islam," I'tibar, vol. 5, no. 10, pp. 49-64, 2018.

[12] Kusuma Iskandar Wiryo, Demokratisasi Belajar dan Pembelajaran Ditinjau dari Pengalaman Empirik,. 2001.

[13] Adyllah Idi dan Toto Suharto, Revitalisasi Pendidikan Islam. .

[14] D. Rosyada, Paradigma Pendidikan Demokratis. Dede Rosyada, Paradigma Pendidikan Demokratis.

[15] Firdaus M. Yunus, Pendidikan Berbasis Realitas Sosial; Paulo Freire dan Y.B Mangunwijaya, Cet. III. Yogyakarta: Logung Pustaka, 2007.

[16] M. L. Fauzi, “'Religion Symbolism and Democracy Encountered,”, ,State Inst. Islam. Stud., vol. Volum, 2012.

[17] Lewis . Bernard, Islam Liberalisme Demokrasi Membangun Sinerji Warisan sejarah, terj. Mun 'im A. Sirry,. Jakarta: Paramadina, 2002.

[18] A. Mustakim, "Mendialogkan Islam dan Demokrasi; Persimpangan Doktrin dan Implementasi, dalam," J. Profetika,Jurnal Stud. Islam., vol. Vol. 4, No, p. 47, 2002.

[19] A. Amir Aziz, Neo Modernisme Islam di Indonesia; Gagasan sentral Nurcholis Madjid dan Abdurrahman Wahid, vol. Cet. I,. 1999.

[20] A. Gofur, Ilmu Pendidikan Islam,. (Jakarta: Insan Media Group, 2010.

[21] A. Gofur, l Ilmu Pendidikan Islam,. Jakarta: Insan Media Group, 2010.

[22] L. . Bernard, Islam Liberalisme Demokrasi Membangun Sinerji Warisan sejarah, terj. Mun'im A. Sirry,. Jakarta: Paramadina, 2002.

[23] M. Al-Buraey, Islam: Landasan Alternatif Administrasi Pembangunan, terj. Achmad Nashir Budiman,. Jakarta: Rajawali, 1986. 
[24] Benn Stanley I., “'Democracy', dalam Paul Edwards (ed. in chief) The Encyclopedia of Philosophy," "Democracy, vol. I, p. 338, 1967.

[25] M. A. Al Abrasy, Beberapa Pemikiran Pendidikan, T erjemah Syamsudin Asyrofi dkk. (Yogyakarta: Titian Ilahi Pers,: Titian Ilahi Pers, 1996.

[26] N. Madjid, Islam ke-Moderenan dan k e-Indonesiaan. Bandung: Mizan, 1991.

[27] Nata .Abuddin, Pemikiran Para Tokoh Pendidikan Islam. Jakarta: PT Raja Grafindo Persada, 3000 .

[28] Ramayulis, Ilmu pendidikan Islam. Jakarta: Ilmu kalam muliamm, 2002.

[29] S. Romlah, "Demokrasi Pendidikan Islam," J. Stud. Islam Pancawahana, vol. 13, no. 2, p. 45, 2018.

[30] A. M. Mulhan, Paradigma Intelektual Muhammad Muslim, Pengantar Filsafat pendidikan Islam,. Yogjakarta: SIPRES, 1993.

[31] M. Fajar, Malik Fajar, Reorientasi Pendidikan Islam. .

[32] M. Ilyasin, "Epistemologi Pendidikan Islam Monokoyomik : Menakar manajemen Pendidikan Paripurna Berbasis Rasionalistik Wahyuistik," Atturas, vol. Vol. 3 No.

[33] "http://restuillahi.blogspot.com/2011/07/dikotomi-ilmu-pengetahuan.html, diakses tanggal 5 Nopember 2019,pukul 19.38."

[34] N. Uhbiyati, Ilmu Pendidikan Islam. Bandung: Pustaka Setia, 2005.

[35] S. dan S. Bahreisy, Ilmu Pendidikan Islam,. Surabaya: Bina Ilmu, 2005.

[36] M. . A. i Al-Abrasy, Dasar-Dasar Pokok Pendidikan Islam., Jakarta: , PT. Bulan Bintang, 1984.

[37] M. R. Daulay, "Demokrasi Pendidikan Dalam Perspektif Filsafat Pendidikan Islam," Fitrah J. Kaji. Ilmu-ilmu Keislam. J. Kaji. Ilmu-ilmu Keislam., vol. 3, no. 1, pp. 91-110, 2017.

[38] A.-A. Abdurrahman bin Muhammad Khaldun, Mukaddimah Ibnu Khaldun, Cet. Ketig. Beirut: Dar Al-Kitab Al-'Arabi, 2005.

[39] R. · A. van H. Maseland, "Why Muslims like democracy yet have so little of it," Inst. Int. Econ. Bus. Manag. Univ. Groningen, PO Box 800, 9700 AV, Groningen, Netherlands, vol. DOI 10.100, p. 481, 2011.

[40] A. R. Setiawan, "Islamic Education in Southeast Asia," vol. 2, no. April, pp. 1-10, 2020.

[41] I. Ahmad, "Islam, democracy and citizenship education: an examination of the social studies curriculum in Pakistan," Curr. Issues Comp. Educ., vol. 7, no. 1, pp. 39-49, 2004.

[42] Tim Pustaka Poenix, Kamus Besar Bahasa Indonesia Edisi Baru, (Cet. IV. Jakarta: Media Pustaka Poenix, 2009.

[43] Mahmud, Mahmud, Pemikiran Pendidikan Islam, Cet. I; Bandung: Sahifa, 2005. h. 51. Bandung: Sahifa, 2005.

[44] Suyanto, Dinamika Pendidikan Nasional [Dalam Percaturan Dunia Global],. Jakarta.: PSAP Muhammadiyah, 2006.

[45] H. A. H. Sanaky, "Metode Tafsir [Perkembangan Metode Tafsir Mengikuti Warna atau Corak Mufassirin]," Al-Mawarid J. Islam. Law, vol. 18, 2008.

[46] M. Yamin, Paradigma Baru Pembelajaran, (Cet. I. ; Jakarta: Gaung Persada Press, 2011. 
[47] A. Tafsir, Filsafat Umum: Akal Dan Hati Sejak Thales Sampai Capra. Bandung: Rosda Karya, 2011.

[48] R. Mudyahardjo, Pengantar Pendidikan. Jakarta: Raja Grafindo Persada, 2002.

[49] El-Tarbawi, “Jurnal Pendidikan Islam No. 1,” J. Pendidik. Islam No. 1, vol. 1, p. 85, 2008.

[50] Muhaimin, "Mengurai Benang Kusut Dunia Pendidikan," Nuansa Baru Pendidik. Islam, 2006.

[51] A. R. Rodger, Educational and Faith in Open Society,. Britain: The Handel Press, 1982.

[52] M. A. Humaedi, "Pendidikan Integral Keilmuan Keagamaan Dan Konteks Sosial Kebudayaan Dalam Menjawab Isu-Isu Kontemporer," EDUKASI J. Penelit. Pendidik. Agama dan Keagamaan, vol. 11, no. 3, pp. 305-318, 2013.

[53] K. Badaruddin, Filsafat Pendidikan Islam. Yogyakarta: Pustaka Pelajar, 2007.

[54] N. Saada, "Perceptions of democracy among Islamic education teachers in Israeli Arab high schools," J. Soc. Stud. Res., vol. 44, no. 3, pp. 271-280, 2020. 